Pobrane z czasopisma Annales H - Oeconomia http://oeconomia.annales.umcs.pl Data: 26/04/2023 16:47:08

DOI:10.17951/h.2015.59.3.39

\begin{tabular}{lcc}
\hline \multicolumn{3}{c}{ A N N A L E S } \\
UNIVERSITATIS & MARIAE CURIE-SKŁODOWSKA \\
LUBLIN - POLONIA & \\
VOL. XLIX, 3 & SECTIOH H \\
\hline
\end{tabular}

Warsaw School of Economics, Institute of International Management and Marketing

LIDIA DANIK

ldanik@sgh.waw.pl

\title{
Information Sources Applied in Search for a Foreign Business Partner and the Perception of Barriers in Establishing International Cooperation
}

Źródła informacji wykorzystywane w poszukiwaniu zagranicznych partnerów biznesowych a postrzeganie barier w nawiązywaniu współpracy międzynarodowej

Keywords: international cooperation barriers, Polish exporters, Polish importers, information sources. Słowa kluczowe: bariery współpracy międzynarodowej, polscy eksporterzy, polscy importerzy, źródła informacji.

JEL Code: F23

\section{Introduction}

The choice of a proper business partner is crucial for international cooperation performance because it determines the resources and skills available to the alliance (Geringer, 1991; Dong, Glaister, 2006). Companies use different sets of partner selection criteria which can be divided into partner-related (i.e. partner's knowledge of the local market, reputation of partner, quality of partner's management team) and task-related (access to knowledge of the local market, access to knowledge of the local culture, access to distribution channels) selection criteria (Geringer, 1991; Ekrem, 2000; Wang, Kess, 2006). Whether the chosen partner is the best one possible, depends not only on the set of the criteria applied, but also on the scope of knowledge concerning the potential partner. 
Entering a foreign market is a learning process (Johanson, Vahlne, 1977). Effective information management is essential for firms operating / conducting their business activities on foreign markets (Belich, Dubinsky, 1995; Theodosiou, Katsikea, 2013). This study concentrates on the question of the sources of information applied in search of foreign partners by Polish exporters and importers. The aim of the paper is to prove whether the perception of barriers hampering establishment of cooperation with partners coming from a given country is related to the mode of looking for a foreign partner from such a country.

\section{Literature review}

In search of foreign partners both internal and external information sources can be used. According to the study of Bartosik-Purgat and Schroeder (2014), Polish exporters perceive the following internal information sources to be most useful: own knowledge and experience of a firm's employees, offers, trade correspondence, trade contracts and invoices. Among the external information sources, the publications and institutional sources are not perceived to be very useful (professional journals, dailies, competitor's catalogues, and examples of competitor's products got the highest scores among publications and business intelligence units, and national economic chambers and Polish Agency for Enterprise Development are perceived to be the most important institutional sources. However, the mean scores of all the institutional sources are below "small significance"). Some other external sources of information classified by authors as "other external sources" are ranked very high. Among the most important are: the Internet, exchange of experience, international fairs and exhibitions, and main foreign customers. The authors also stated that, "the analysis suggests that different information sources offer different advantages with none emerging as superior in all situations".

Belich and Dubinski (1995) identified a set of factors affecting the choice of information source: the product differentiation, export intensity, product maturity, product complexity, market distance, and international competition. Bartosik-Purgat and Schroeder (2014) put more stress on the market characteristics and list the following factors determining the character, number and extent of the usage of sources of information concerning foreign markets and partners: size of an enterprise, export phase, information-providing institutions, cultural differences and uncertainty of the environment.

Previous studies rely rather on the market and company level. As decisions about the information sources applied when looking for a new partner are made not by companies but by people, one can suspect that the decision maker's mindset can also be one of the determinants of the mode of searching for the partner. Perception of the cooperation barriers is one of the elements of the decision maker's mindset.

Most of the studies devoted to the cooperation barriers or international cooperation barriers concentrate on listing the barriers perceived to be important. Only in 
some studies did authors attempt to capture the relationships between the barriers perception and other phenomena (i.e. Lewandowska, Danik, 2014).

There is no agreement in the literature about the list of potential international cooperation barriers, as all the studies take into account slightly different aspects of the cooperation. However, after studying the literature devoted to cooperation barriers (Nowak 2009; Zaremba, 2009; Stępień, 2011), to open innovation barriers (Chesbrough, 2003; Gassmann, 2006; Van de Vrade et al., 2009) or finally to internationalization and international cooperation barriers (Artega-Ortiz, Fernández-Ortiz, 2010; Dmitrov et al., 2003; Leick, 2011), one can identify a set of factors which are believed to hamper the establishment of cooperation with a partner from a given country (see Table 1).

Table 1. Barriers hampering establishing international cooperation

\begin{tabular}{|c|c|c|}
\hline $\begin{array}{l}\text { Barriers related to distance } \\
\text { (macro-level barriers) }\end{array}$ & $\begin{array}{l}\text { Internal barriers (barriers related to the } \\
\text { company's resources, including lack of } \\
\text { external support for a given company) }\end{array}$ & Fears related to relationship \\
\hline $\begin{array}{l}\text { Distance (geographical distance); } \\
\text { Technological barrier; } \\
\text { Language barrier; } \\
\text { Different way of conducting } \\
\text { business in partner's country; } \\
\text { Different level of economic } \\
\text { development; } \\
\text { Political differences; } \\
\text { Legal system differences. }\end{array}$ & $\begin{array}{l}\text { Low experience in the partner's country; } \\
\text { The necessity to adapt to the partner's } \\
\text { needs; } \\
\text { High cooperation costs; } \\
\text { Lack of employees who could coordinate } \\
\text { the international cooperation }{ }^{\mathrm{TM}} \text {; } \\
\text { Lack of government and government } \\
\text { agencies support for the international } \\
\text { cooperation. }\end{array}$ & $\begin{array}{l}\text { Fear of becoming dependent } \\
\text { on the partner; } \\
\text { Fear of having our know-how } \\
\text { copied; } \\
\text { Fear of being eliminated from } \\
\text { the market because of the } \\
\text { partner's activities; } \\
\text { Fear to lose own identity } \\
\text { because of undue } \\
\text { subordination to the partner; } \\
\text { Fear that the partner can take } \\
\text { our staff over. }\end{array}$ \\
\hline
\end{tabular}

Source: own elaboration

\section{Research methodology and sample characteristics}

The study was conducted on a total sample of 280 companies in January and February 2013 using the CATI method. The respondents were Polish manufacturing SMEs cooperating with partners from China and Germany (the cooperation was defined as relationships lasting for at least one year and consisting in a regular, not one-time, tasks completion by partners when the partners are independent, i.e. with no capital ties, or (if capital ties exist) when none of the firms enjoys supervision powers over the partner (Stępień, 2011, pp. 15-33). The respondents were people responsible for cooperation with foreign partners (sales, export and marketing directors and company owners, followed by sales, export and marketing managers). Two companies not fulfilling the criterion of SMEs were not considered in the further analysis. The final sample comprised 64 exporters to China, 84 importers of goods from China, 83 exporters to Germany and 76 importers of goods from Germany. 
Twenty four of the companies under study employed less than 10 people, $107 \mathrm{com}$ panies: 10-49 people and 147 companies: 50-249 people. In most cases the scope of the cooperation with foreign partners was limited to export-import transactions and services connected with manufacturing and distribution.

The perception of barriers was examined with the question: "To what extent the factors mentioned below hamper establishment of the cooperation with partners from China / Germany?" followed by a list of barriers. A 5-point Likert type scale was applied from 1 (this factor definitely does not make it difficult for us to establish cooperation) to 5 (this factor definitely does make it difficult for us to establish cooperation). Companies cooperating with partners from China were asked about factors hampering the cooperation with Chinese partners, and companies cooperating with partners from Germany were asked about barriers in establishing cooperation with German partners. The cooperation barriers the respondents were asked about are presented in Table 1.

The Cronbach's alpha coefficient was low (under 0.6) for the internal barriers scale. Therefore, in order to identify the number of underlying factors an exploratory factor analysis using Oblimin rotation with Kaiser normalization was conducted and the barriers under study were grouped $\left(\mathrm{KMO}=0.784 ; \mathrm{x}^{2}(136)=1031.25 ; \mathrm{p}<0.001\right)$ into distance and internal barriers and fears related to relationship. The Cronbach's alpha for both groups are between 0.693 in case of importers from China and 0.832 in case of exporters to Germany. The barriers comprising the identified groups and the factor loadings are presented in Table 2 .

Table 2. Rotated factor matrix - barriers to establishing international cooperation

\begin{tabular}{|l|c|c|}
\hline Barriers & $\begin{array}{l}\text { Distance and } \\
\text { internal barriers }\end{array}$ & $\begin{array}{l}\text { Fears related } \\
\text { to relationship }\end{array}$ \\
\hline Technological barrier & 0.600 & 0.584 \\
\hline Different level of economic development & 0.558 & \\
\hline Political differences & 0.548 & \\
\hline Different way of conducting business in partner's country & 0.534 & \\
\hline Legal system differences & 0.531 & \\
\hline High cooperation costs & 0.525 & \\
\hline The necessity to adapt to the partner's needs & 0.513 & \\
\hline Distance (geographical) & 0.509 & \\
\hline Lack of employees who could coordinate the international cooperation & 0.474 & \\
\hline Low experience in the partners country & 0.458 & \\
\hline Language barrier & 0.356 & \\
\hline $\begin{array}{l}\text { Lack of government and government agencies support for the international } \\
\text { cooperation }\end{array}$ & & -0.821 \\
\hline Fear to lose own identity because of undue subordination to the partner & & -0.769 \\
\hline Fear of being eliminated from the market because of the partner's activities & & -0.704 \\
\hline Fear of becoming dependent on the partner & & -0.650 \\
\hline Fear that partner can take our staff over & & -0.644 \\
\hline Fear of having our know-how copied & & \\
\hline
\end{tabular}

Rotation converged in 5 iterations.

Source: own elaboration 


\section{Research results}

A k-means cluster analysis was applied in order to verify if the question concerning the barriers perception allows to split the sample into two or more independent clusters. The analysis confirmed the existence of two clusters (the Silhouette coefficient for the first cluster is above 0.66 , and for the second one -0.68 , which confirms the proper cohesion and separation of the identified groups). The first cluster (low barriers cluster) comprises 131 companies, and the second one (high barriers cluster) -147 . The clusters are presented in Figure 1.

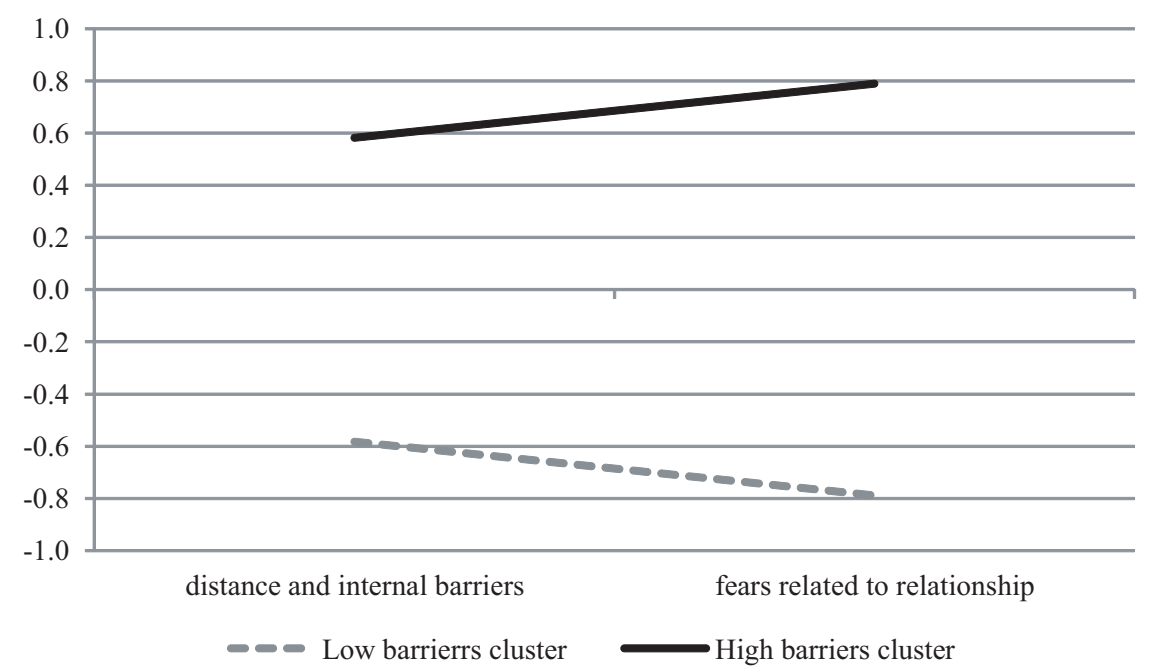

Figure 1. International cooperation barriers perception clusters

Source: own elaboration

In the low barriers cluster, both distance and internal barriers, and fears related to relationship are perceived to be lower than in the second cluster.

The low barriers cluster consists of $47.7 \%$ exporters and $52.3 \%$ importers. The structure of the second cluster is very similar: $48.4 \%$ of the companies are exporters and $51.6 \%$ - importers. The chi-square test did not reveal any significant differences between the clusters concerning cooperation direction (export / import). $42.9 \%$ of the companies in the low barriers cluster cooperate with Chinese partners and $57.1 \%$ with German partners, whereas the situation in the second cluster is the opposite: $57.5 \%$ of the companies cooperate with Chinese partners and $42.5 \%$ - with German ones. According to the chi-square test, the clusters differ significantly $(\mathrm{p}<.05)$ in terms of the partner's country of origin.

The information sources applied while looking for new partners were explored with the use of the question, "How do you look for partners from China / Germany" 
followed by a list of possible information sources used to find a partner. A 5-point Likert type scale was applied from 1 (we never make/made use of this way) to 5 (we always take advantage of this way). Then the second question "Do you verify the partner's credibility before taking the decision about establishing cooperation?" was asked with a scale: 1 (yes, always), 2 (yes, sometimes) and 3 (no, never). Those who answered "yes" (answer 1 or 2) were asked the next question: "How does your company verify the partner's credibility?" followed by a list of possible ways / information sources which can be used to verify the credibility. The scale was the same as in the question about ways of looking for a partner.

In order to investigate if belonging to one of the clusters described above is connected with different information sources applied while looking for the partners, a t-Student test for independent samples was conducted (see Table 3).

Table 3. Descriptive statistics and t-Student test results for clusters

\begin{tabular}{|c|c|c|c|c|c|c|c|}
\hline & & \multicolumn{2}{|c|}{$\begin{array}{l}\text { Low barriers } \\
\text { cluster }\end{array}$} & \multicolumn{2}{|c|}{$\begin{array}{l}\text { High barriers } \\
\text { cluster }\end{array}$} & \multirow[t]{2}{*}{$\mathrm{t}$} & \multirow{2}{*}{$\mathrm{p}$} \\
\hline & & M & $\mathrm{SD}$ & $\mathrm{M}$ & $\mathrm{SD}$ & & \\
\hline \multirow{7}{*}{ 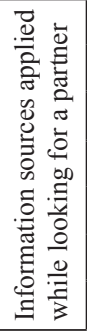 } & Internet & 3.072 & 1.527 & 3.313 & 1.425 & -1.361 & 0.175 \\
\hline & Personal network & 3.550 & 1.361 & 3.371 & 1.260 & 1.143 & 0.254 \\
\hline & Commercial brokers & 1.601 & 1.075 & 1.795 & 1.016 & -1.548 & 0.123 \\
\hline & Trade fairs & 3.094 & 1.487 & 3.277 & 1.253 & -1.112 & 0.267 \\
\hline & Trade catalogues & 2.219 & 1.243 & 2.446 & 1.268 & -1.505 & 0.133 \\
\hline & Trade missions & 1.478 & 0.924 & 1.784 & 0.933 & -2.745 & 0.006 \\
\hline & Partners connect us by themselves & 3.406 & 1.252 & 3.191 & 1.072 & 1.544 & 0.124 \\
\hline \multicolumn{2}{|c|}{$\begin{array}{l}\text { Verifying partner's reliability before taking the } \\
\text { cooperation decision }\end{array}$} & 2.403 & 0.787 & 2.612 & 0.654 & -2.404 & 0.017 \\
\hline \multirow{13}{*}{ 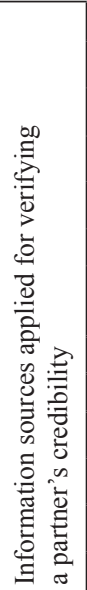 } & Credit information agencies & 2.658 & 1.569 & 2.933 & 1.420 & -1.429 & 0.154 \\
\hline & Chambers of commerce & 1.810 & 1.209 & 2.294 & 1.141 & -3.183 & 0.002 \\
\hline & Court registers & 2.500 & 1.605 & 2.718 & 1.369 & -1.134 & 0.258 \\
\hline & Industrial services & 2.345 & 1.439 & 2.671 & 1.324 & -1.821 & 0.070 \\
\hline & Internet forums & 2.071 & 1.353 & 2.373 & 1.203 & -1.828 & 0.069 \\
\hline & Ratings, rankings & 1.827 & 1.202 & 2.075 & 1.114 & -1.655 & 0.099 \\
\hline & $\begin{array}{l}\text { Prospectuses, information memorandums and } \\
\text { information published by stock exchanges }\end{array}$ & 1.363 & 0.780 & 1.798 & 0.928 & -3.897 & 0.000 \\
\hline & Print media & 1.642 & 1.034 & 1.901 & 1.014 & -1.955 & 0.052 \\
\hline & Bank information & 2.040 & 1.316 & 2.345 & 1.274 & -1.822 & 0.070 \\
\hline & Face-to-face visits in partner's company & 3.681 & 1.309 & 3.778 & 1.174 & -0.600 & 0.549 \\
\hline & Comparison of offers & 3.438 & 1.597 & 3.806 & 1.217 & -2.013 & 0.045 \\
\hline & Partner's webpages & 3.301 & 1.558 & 3.492 & 1.302 & -1.033 & 0.303 \\
\hline & Partner's social media profiles & 1.412 & 0.922 & 1.901 & 1.008 & -3.901 & 0.000 \\
\hline
\end{tabular}

Source: own elaboration 
The analysis revealed one significant difference between clusters in case of comparing the information sources used for finding potential partners: companies from the high barrier clusters were looking for new partners taking advantage of trade missions relatively more often. Moreover, they were also more readily verifying partner's reliability before making the decision about cooperation. Also, the analysis of the information sources applied for verifying partner's credibility showed some significant differences: companies from this cluster took advantage of the chambers of commerce, prospectuses, information memorandums, and information published by stock exchange, compared offers and analyzed partner's social media profiles more frequently.

Both groups have a lot in common: Internet, personal network, and trade fairs were the mostly used information sources for finding new partners. Surprisingly, many of the companies under study were just found and contacted by future partners. For both clusters the most favorite ways of verifying partner's credibility were face-to-face visits in partner's company, comparison of offers and verifying partner's webpages.

As significant differences between the clusters in the partner's country of origin were observed, additional analysis was conducted in order to check if there is no country moderation effect between belonging to one of the clusters identified and the way of looking for and verifying a business partner. A two-way analysis of variance did not show any country moderation effect (see Table 4). Therefore one can assume that the effects observed do not depend on the partner's country of origin.

Table 4. Partner's country of origin influence on the dependence between belonging to one of the clusters and the way of looking for and verifying a business partner

\begin{tabular}{|l|c|c|}
\hline Dependent variable & $\mathrm{F}$ & $\mathrm{P}$ \\
\hline Internet & 0.045 & 0.831 \\
\hline Personal network & 0.461 & 0.498 \\
\hline Commercial brokers & 0.517 & 0.473 \\
\hline Trade fairs & 0.017 & 0.896 \\
\hline Trade catalogues & 1.517 & 0.219 \\
\hline Trade missions & 0.562 & 0.454 \\
\hline Partners connect us by themselves & 2.778 & 0.097 \\
\hline Verifying partners reliability before taking the cooperation decision & 0.121 & 0.728 \\
\hline Credit information agencies & 3.734 & 0.055 \\
\hline Chambers of commerce & 0.444 & 0.506 \\
\hline Court registers & 0.054 & 0.817 \\
\hline Industrial services & 2.253 & 0.135 \\
\hline Internet forums & 0.116 & 0.733 \\
\hline Ratings, rankings & 0.652 & 0.420 \\
\hline Prospectuses, information memorandums and information published by stock exchanges & 0.974 & 0.325 \\
\hline Print media & 0.169 & 0.681 \\
\hline Bank information & 3.107 & 0.079 \\
\hline Face-to-face visits in partner's company & 0.797 & 0.373 \\
\hline Comparison of offers & 0.040 & 0.841 \\
\hline Verifying partner's Webpages & 0.344 & 0.558 \\
\hline Verifying partner's social media profiles & 0.002 & 0.965 \\
\hline
\end{tabular}




\section{Conclusions}

In this study, two clusters of Polish companies cooperating with Chinese and German partners were identified. This clusters differed in the perception of barriers in establishing the cooperation with partners from China / Germany, especially in respect to fears related to the relationship. Although the information sources used in the search for a new partner were in many cases similar, some significant differences, especially in the way of verifying partner's reliability, were found which leads to the conclusion that the approach toward the cooperation influences the behavior of the companies (in this case: verifying the partner's reliability and use of the information sources). Companies, which see more barriers are more cagy and tend to verify the potential partner more carefully. This phenomenon can be probably chalked up to the lower trust level.

Although the study is a contribution to the international business theory, it also has some limitations. Only Polish companies cooperating with Chinese and German partners were studied, so one cannot draw conclusions concerning other companies. Moreover, the perception of barriers is probably not the only factor explaining the approach towards information sources. The other factors should be identified in the future studies.

\section{References}

1. Artega-Ortiz J., Fernández-Ortiz R., Why Don't We Use the Same Export Barrier Measurement Scale? An Empirical Analysis in Small and Medium-Sized Enterprises, Journal of Small Business Management, 2010, Vol. 48, No. 3.

http://dx.doi.org/10.1111/j.1540-627x.2010.00300.x

2. Bartosik-Purgat M., Schroeder J., Polish exporters' use and perception of various sources of market information, Poznań University of Economics Review, 2014, Vol. 14, No. 2.

3. Belich T.J., Dubinsky A.J., Factors Related to Information Acquisition in Exporting Organizations, Journal of Business Research, 1995, Vol. 33, No. 1. http://dx.doi.org/10.1016/0148-2963(94)00001-U

4. Chesbrough H.W., Open Innovation: The New Imperative for Creating and Profiting, Boston: Harvard Business School Press, 2003.

5. Dmitrov M., Petrakos G., Totev S., Tsiapa M., Cross-Border Cooperation in Southeastern Europe the Enterprises'Point of View, Eastern European Economics, 2003, Vol. 41, No. 6.

6. Dong L., Glaister K.W., Motives and partner selection criteria in international strategic alliances: Perspectives of Chinese firms, International Business Review, 2006, Vol. 15. http://dx.doi.org/10.1016/j.ibusrev.2006.09.003

7. Ekrem T., Western joint ventures in Turkey: strategic motives and partner selection criteria, European Business Review, 2000, Vol. 12, No. 3.

8. Gassmann O., Opening up the innovation process: towards an agenda, R\&D Management, $2006, \mathrm{Vol}$. 36, No. 3 . http://dx.doi.org/10.1111/j.1467-9310.2006.00437.x 
9. Geringer J.M., Strategic determinants of partner selection criteria in international joint ventures, Journal of International Business Studies, 1991, Vol. 22, No. 1.

http://dx.doi.org/10.1057/palgrave.jibs.8490291

10. Johanson J., Vahlne J.-E., The Internationalization Process of the Firm-A Model of Knowledge Development and Increasing Foreign Market Commitments, Journal of International Business Studies, 1977, Vol. 8, No. 1.

http://dx.doi.org/10.1057/palgrave.jibs.8490676

11. Leick B., Barriers to co-operation and competitive advantage: Cross border business networks of Saxon and Northern Bohemian firms, Journal for East European Management Studies, 2011, Vol. 16, No. 2 .

12. Lewandowska M., Danik L., Bariery a skłonność do kooperacji w innowacjach polskich eksporterów - wyniki badań, Gospodarka Materiałowa \& Logistyka, 2014, Vol. 2.

13. Nowak D., Bariery rozwoju powiazań kooperacyjnych w ocenie polskich przedsiębiorstw, Zeszyty Naukowe Uniwersytetu Szczecińskiego, (to be published), Stępień B. ed. Międzynarodowa kooperacja gospodarcza z polskiej perspektywy, Warszawa: Polskie Wydawnictwo Ekonomiczne, 2011.

14. Stępień B. (ed.), Międzynarodowa kooperacja gospodarcza z polskiej perspektywy, Warszawa: Polskie Wydawnictwo Ekonomiczne, 2011.

15. Theodosiou M., Katsikea E., The Export Information System: An Empirical Investigation of Its Antecedents and Performance Outcomes, Journal of International Marketing, 2013, Vol. 21, No. 3. http://dx.doi.org/10.1509/jim.12.0165

16. Van de Vrade V., de Jong J.P.J., Vanhaverbeke W., de Rochemont M., Open innovation in SMEs: Trends, motives and management challenges, Technovation, 2009, Vol. 29. http://dx.doi.org/10.1016/j.technovation.2008.10.001

17. Wang L., Kess P., Partnering motives and partner selection. Case studies of Finnish distributor relationships in China, International Journal of Physical Distribution \& Logistics Management, 2006, Vol. 36, No. 6.

18. Zaremba M., Wymiana danych pomiędzy średnimi przedsiębiorstwami a ich kontrahentami, Gospodarka Materiałowa \& Logistyka, 2009, Vol. 1.

\section{Information Sources Applied in Search for a Foreign Business Partner and the Perception of Barriers in Establishing International Cooperation}

Abstract. The aim of the paper is to analyze the relationship between the perception of the barriers in establishing an international cooperation and information sources applied while looking for foreign partners. The paper presents the results of the study on 278 Polish exporters and importers cooperating with partners from China and Germany. The companies were divided in two clusters differing in the perception of the barriers in establishing the cooperation with partners from China and Germany. The analysis revealed that these clusters differ only to a modest extent regarding the information sources applied to find a foreign partner. However, significant differences regarding the way of verifying the partner's reliability were shown. This effect did not depend on the partner's country of origin.

\section{Źródła informacji wykorzystywane w poszukiwaniu zagranicznych partnerów biznesowych a postrzeganie barier w nawiązywaniu współpracy międzynarodowej}

Abstrakt. Celem artykułu jest analiza związku postrzegania barier w nawiązywaniu współpracy międzynarodowej oraz źródeł informacji wykorzystywanych podczas poszukiwania partnera zagranicznego. Zaprezentowano wyniki badania 278 polskich eksporterów i importerów współpracujących z partnerami 
Pobrane z czasopisma Annales $\mathrm{H}$ - Oeconomia http://oeconomia.annales.umcs.pl

Data: 26/04/2023 16:47:08

LIDIA DANIK

z Chin i z Niemiec. Przedsiębiorstwa podzielono na dwa skupienia w zależności od postrzegania przez nie barier w nawiązywaniu współpracy z partnerami z Niemiec i z Chin. Analiza wykazała, że skupienia te w niewielkim stopniu różnią się między sobą jeśli chodzi o źródła informacji wykorzystywane podczas poszukiwania partnera zagranicznego, natomiast występują między nimi istotne różnice dotyczące sposobu weryfikacji wiarygodności potencjalnego partnera. Efekt ten występował niezależnie od kraju pochodzenia partnera. 